Brit. J. industr. Med., 1962, 19, 297.

\title{
THE BEGINNINGS OF INDUSTRIAL MEDICINE IN ENGLAND*
}

\author{
BY \\ H. BUESS + \\ From the Department of Industrial Medicine CIBA Ltd., Basle, Switzerland
}

(RECEIVED FOR PUBLICATION JUNE 1, 1962)

\begin{abstract}
Industrial medicine saw its tentative beginnings among the inquiring minds of 16 th century physicians such as Paracelsus. In the 17th century, reports of conditions in mines on the Continent prompted natural scientists at the Royal Society to initiate a research programme into what we now know as mercurial poisoning. The latter part of the eighteenth century witnessed the change from domestic to factory industry with its concomitant social, economic, and technological upheaval, resulting in great shifts of population away from the countryside to the towns. Men, women, and children were employed in the new factories in primitive, unhygienic conditions, and mill fever and illness generally wcre rife. It was against this background that Percival and Thackrah, prompted no doubt in large measure by the conditions of child labour, inquired into, and made recommendations for, the improvement of hygiene in the factories, thus laying the foundations of industrial medicine as we know it today.
\end{abstract}

In 1825 Goethe wrote in a letter to Zelter (quoted from Joël, 1929-34, Vol. II, p. 600): "Wealth and speed are what the world admires-railways, rapid posts, steamships, and all the facilities of communication are what the educated world is aiming atthis is really a century for practical men, even if their talents are not of the highest order". How aptly these words apply to such a limited field as industrial medicine. In our mind's eye we can picture those soot-blackened, remote villages of England where miners' families eked out their monotonous existence. Life at that time was ruled by the mine on the one hand and by the factory on the other-the factory which Sombart, the wellknown German sociologist, called "the tool of the collective worker, by means of which he is able to develop a strength, refinement, security, and speed that go beyond the limits of organic life, and to transform the most fundamental idea of modern technology into reality" (loc. cit., Vol. II, p. 676).

This modern technology has rightly been described as one of the strangest offshoots of romanticism. Inspired by their sense of wonder and by their eagerness to embrace what was new, the men who lived in the later years of the age of enlighten-

\footnotetext{
*From Schweiz. med. Wschr. (1960), 90, 443, and published with the permission of the Editor.

+ Part time Professor of Medical History, University of Basle.
the permission of the Editor.
}

ment created out of their rich imaginations masterpieces of mechanical engineering. The selfsame offshoot, however, in the age of organized labour produced a second fruit-socialism, derived from the ideas of the great philosopher Hegel. The romantic ideal of love, which had inspired Hegel in his formative years, developed via an organic process into an awareness of social solidarity, and it is this awareness that really characterizes the famousand notorious-"objective spirit" of the Prussian scholar.

It was during these decisive years, the mental climate of which we have outlined from a Central European standpoint, that the so-called Industrial Revolution took place. With certain differences as regards its various phases, it followed a more or less uniform pattern in all countries. We are primarily interested here in the conditions in Great Britain, for the simple reason that what happened on this island can be regarded as typical. But if we want to examine the beginnings of the revolution, we must once again go back to the 17th century, because in the world of industry, too, it was the inquiring spirit of the enthusiastic inventors of that age, which laid the first foundations for a medical study of occupational diseases.

I shall try to show briefly how these beginnings eventually gave rise to a broad basis on which 
industrial medicine could develop the profusion of highly differentiated methods of investigation and prevention which we know today.

\section{I.}

It would take too long to describe in detail the origins of the study of occupational diseases. Quite generally, however, it may be said that this field, too, was first opened up by the exploring minds of Renaissance doctors. The first author to concern himself with industrial medicine was Paracelsus, whose three books on miners' diseases ("Von der Bergsucht und anderen Bergkrankheiten") are of paramount historical importance. The manual compiled by Georg Agricola, "De re metallica" (1556), which had been published in Basle a short time previously, may well have proved valuable to mine owners-mining was already a widespread industry in those days-chiefly as a technical compendium, but also as a guide to hygiene (Buess, 1961).

The Continental type of mine, found mainly in Saxony, the Alpine regions, and the foot-hills of the Pyrenees, aroused intense interest among the enterprising members of the Royal Society which was founded about the middle of the 17th century. The English, with their practical turn of mind, were quick to recognize that this type of mining could provide them with a host of new ideas suited to their own needs. They were, in fact, anxious to find more rational methods of exploiting the deposits of ore that had already been discovered at an earlier date, and to replace charcoal, which was gradually disappearing, by the far more appropriate hard coal. The English were thus impelled for both scientific and economic reasons to strike out in a new direction. It has been too little appreciated in the past that this trend also had an important bearing on the history of industrial medicine.

The "Philosophical Transactions", which are still extant today, was among the publications of the newly-formed Royal Society. The first volume, published in 1665, included several contributions, most of them in the form of letters, which bore witness to the force of the new impetus. The Dean of Wadham College, Oxford, at that time, Walter Pope (died 1714), who had made a name for himself as an astronomer and obtained the degree of Doctor of Medicine in 1661, seems to have been responsible for initiating a special research programme. As reported in the second number of the "Philosophical Transactions", which appeared on April 3, he visited, on one of his numerous journeys, the "mines of mercury in Friuli" on the Adriatic. Besides giving important details of a technical and economic nature, his letter also contains a reference to the diseases of the workers, all of whom became sooner or later "paralitick" and died "hectick", i.e. of consumption. Pope was also informed that this "palsey" was likewise common among mirror makers in Venice.

These observations relate to the most prominent symptoms of mercurial poisoning, as known at that time. An additional important factor in these cases of paralysis was perhaps the marked abuse of alcohol, about which works doctors (Scopoli, Hacquet, cf., Lesky, 1956) were later to make such harrowing reports. However that may be, Pope's brief account, with its laconic medical passage, seems to have deeply impressed the gentlemen of the Royal Society. A similar effect was produced by a review, apparently written by the first secretary of the Royal Society, Henry Oldenburg, who was born in Bremen, on the work "Mundus subterraneus" by the Jesuit priest Athanasius Kircher. The tenth book of this work contains a descriptionmodelled on that of Agricola's among others-of metallurgy, the "Metallick Art", the qualities of a "Mine-master", the disease of "Mine-men" and their cure, and the "waies of purging the Mines of the Airs malignity".

Another report, a really dramatic account of a pit disaster in Scotland, which cost the lives of a number of miners, must have shocked the readers of the "Transactions" (Vol. I, pp. 44 et seq.). This disaster seems to have been caused by fire-damp.

It is not surprising, therefore, that the natural scientists of that time were prompted to study the medical aspects of mining. Robert Boyle, the brilliant and versatile chemist, produced his "General Heads for a Natural History of a Countrey" (loc. cit., p. 186-189), in which he stressed that an account of the most important features of a particular region should be supplemented by "subterraneal observations", extending to the "waters" and "damps" of mines. The editors of the Philosophical Transactions went a step further by publishing a "Set of Inquiries" about mines, which was apparently also compiled by Boyle (pp. 330-343); these "Queries" were given as a vade-mecum to travellers returning home. The fourth of the six "titles" asks, under Queries 44 and 46, the following pertinent questions: "44. What wayes and cautions they use, to free the Mine and secure the Work-men from the inconveniences and danger accruing from the use of much Fire in it. 46. How the Mine-men work; whether naked or cloathed? And what Lights they use to work by; what materials they are made of, what measure of light they give; how long they last? and by what wayes they are kept burning in that thick and foggy air?" 
In a supplement, probably also written by Boyle, it is suggested (Query 5) that information also be obtained about the "Laws, Constitutions, and "Customs, Oeconomical, Political, Ethical, that are receiv'd and practis'd among the Mine-men." Finally (Query 10), reports should indicate how much heavier the atmosphere is at the bottom of the mine than at the top, and whether or not the "damps" appreciably increase this heaviness.

These "Queries" were thus designed to form the basis of a whole programme of technical and social hygiene in the mining industry. This appeal to the members of the Royal Society no doubt had a considerable influence on the aims of natural scientific research in those days. What kind of answers did this inquiry provoke? All we can do here is to refer to the first reports and show that the later volumes also contained articles which may perhaps be connected with this campaign.

Of much interest is the general verdict pronounced by Joseph Glanvil (Vol. I, pp. 525 et seq.) on the population of the mining district in the Mendip Hills, which reads as follows: "That the Natives and Inhabitants live neither longer nor shorter, than ordinary, but live healthy, saving such, as are employed about melting of the Lead at the Mines; who, if they work in the smoak, are subject to a Disease, that will kill them, and the Cattel likewise that feed thereabout. The Smoak, that rests upon the Ground, will bane them. And therefore the Inhabitants have Keepers to keep them from it, for fear of the Infection."

This report on conditions in the Mendip Hills puts one in mind of the fluorosis in North-West Switzerland, which has given rise to serious complaints from farmers in recent years. The danger to cattle in the Mendips may have been caused by lead contamination of their feed. Further reports on the effects produced by metals in human beings are found in the "Philosophical Transactions" during the 17th and 18th centuries, and relate to mines not only in England, but also in Hungary, Germany, Austria, Spain, and America. Occasional cases of carbon monoxide poisoning were reported, as well as explosions and other pit disasters, showing that the natural scientists of that time were men of wide interests. These reports ceased abruptly with the setting up of new industries in the last third of the 18th century. The 40 volumes published from 1781 to 1820 do not contain a single article on this subject, except for the account of Davy's safety lamp (1816).

\section{II.}

It is gratifying to find that doctors-albeit only a few to start with—endeavoured to secure health and safety protection for the workers right from the beginning of that social revolution. Before describing the work of two of these doctors, I shall outline briefly the origins of the Industrial Revolution in England.

Undoubtedly, as Georg Rosen showed clearly in his "The History of Miners' Diseases" (1943), mining, which was still actively pursued in Central Europe until the beginning of the 18th century, underwent a sharp decline soon afterwards, some mines even being allowed to go to ruin. How then can we explain the tempestuous pace at which factories and mines began to spring up in England from the middle of the 18th century? The answer to this question is to be sought in cultural and economic developments. In Great Britain, the non-conformist churches started a bitter struggle for freedom in the 17 th century. In the economic sphere, this struggle resulted in an unlimited recognition of free competition, which culminated in the "Declaration of Rights" issued by William III (1689). This declaration paved the way for the second step which was to ensure that the privileges thus obtained were balanced by an increase in production, achieved by the use of machines, the construction of which was considerably facilitated by the English entrepreneur's interest in technical matters. This trend is reflected above all in the rapid, large-scale introduction of the steam engine (Thomas Saverey, 1698; James Watt, 1769). It is significant-for the further development of industrial medicine as well-that the first engines of this type were installed in the mines of Cornwall (for the water pumps) and in the cotton spinning mills. The first factory, in the modern sense of the term, was also a spinning mill, founded by Arkwright in 1771 and operated at first by water power (Michel, 1953).

These developments in the economic and technological fields set the scene for a no less important social process characterized by a mass regrouping of the population. Agricultural workers drifted from the countryside to the towns and the necessary labour became available for the factories.

Women and children were employed to operate the machines-a task that did not demand great physical strength. And it was in fact the employment of children that prompted doctors to concern themselves with conditions in industry. Soon afterwards writers such as Dickens and Elizabeth Barrett Browning took up the theme of social misery, which was also described by John Fielden (1847), (Hunter, 1957).

One of the chief pioneers in this field was Thomas Percival (1740-1804), physician, of Manchester. The following brief account of his life is based on the article in the Dictionary of National Biography. 
Born in Warrington, Lancashire, on September 29, 1740 to a family of shopkeepers, the boy lost both his parents at the age of three and was brought up by an elder sister. An uncle, who was a doctor and who died at an early age, bequeathed to him his library and practice, and this decided Percival to study medicine. After spending his school years in his home town, he went to the universities of Edinburgh and London, where he made the acquaintance of several outstanding personalities (e.g. David Hume). In London, thanks to influential connexions (Lord Willoughby), and perhaps also to his precocious knowledge of medicine, he was elected to membership of the Royal Society when he was only about 20 years old. He took his doctor's degree in Leyden in 1765.

After practising for only a short time in his home town, he set out for the up-and-coming city of Manchester where he remained until he died on August 30, 1804. A man of great personal charm and possessing a profound understanding of social problems, he quickly acquired a considerable reputation, founding, on the one hand, the Literary and Philosophical Society (1781) and, on the other, being elected a member of the Manchester Board of Health. This appointment is of particular interest because it brought Percival into contact at an early date with the poorer people of his district. On January 25,1796 he is reported to have demanded in a petition to the authorities that the workers be ensured effective protection. His attempt to establish a College of Arts and Sciences, however, did not meet with any success.

Percival's astonishing versatility is also apparent from his literary output, which ranged from a popular children's book ("A Father's Instructions", $1775)$ to "Medical Ethics" (1803, 2nd ed. 1827). His "Essays, Medical and Experimental" (Joseph Johnson, London, 1767-1776) made him a great number of friends in Europe and America. These essays included observations on the harmful effects of lead, which were confirmed in experiments on cats. Percival successfully used Leyden jar discharges for therapeutic purposes (as proposed by Anton de Haen). The harmful effects of ingested lead salts and solutions also gave Percival an opportunity to utter an eloquent warning against their use in medical prescriptions.

Of greater interest is Percival's preoccupation with the hazards of gases and dusts. In an essay written in 1773 ("On the Noxious Vapours of Charcoal"), he described succinctly the consequences of the inhalation of carbon monoxide in a domestic servant. He attributed these consequences to a "mephitic air" (in contrast to "factitious or fixed air"), which calls for an entirely different approach. The effects of the gas "destroy the action of the brain and nerves, and in a moment arrest the vital motions" (p. 101). In the light of modern views on the extremely complex mode of action of carbon monoxide, one cannot but admire the clarity with which Percival described the clinical picture. He also gave a well-observed account (pp. 101-102) of a cook suffering from the late sequelae of intoxicationsevere headache and paralysis of the lower limbswhich were studied in great detail by Zangger. His warning never to burn charcoal without ensuring an adequate supply of fresh air, and the first-aid measures he recommended (including artificial mouth-tomouth respiration, which has recently celebrated its come-back, p. 109), bear witness to Percival's perspicacity and to his desire to help his fellow men.

In Manchester, which had rapidly developed into the leading industrial city, the growth of the population confronted the authorities with a special challenge. Percival concerned himself with this problem on several occasions (ibid, pp. 239-250, including two specimen tables-Table of Deaths and Table of Diseases; 1776: "Philosophical, Medical and Experimental Essays", pp. 1-108), and also referred to the influence of "particular trades and manufactures" on life span. There can be no doubt that Percival's statistics, in addition to some of those furnished by earlier writers, had a most salutary effect; his suggestions found an echo in the 19th century (especially in the writings of the statistician William Farr who, incidentally, had also had the benefit of a medical training).

Mention must also be made of a third meritorious achievement of Percival's, to which Rosen (1958) and Meiklejohn (1959) recently referred. This is the report compiled by Percival and three of his colleagues (John Cowling, Alexander Eason, and Edward Chorley) on the outbreak of fever in the Radcliffe cotton mill, which they addressed to the Justice of the Peace in Lancaster on October 8, 1784. Requested by the Justice of the Peace to make an inquiry, they observed among the mill workers a putrid fever of a contagious nature, which also persisted among the poor people of the neighbourhood for several months. Without saying anything about the origin of this fever, Percival and his colleagues reported their conviction that the disorder was promoted, propagated, and intensified by the ease with which contagion spread among the crowded workers. The concern expressed by the mill owners, they said, was encouraging and gave grounds for hope that the preventive measures (recommended in detail) would be successful. The recommendations read for the most part like a modern hygiene notice in a workshop, and take account also of the special conditions obtaining in the cotton industry. 
III.

Soon this Lancashire physician was to find a successor, who has become a kind of modern Aesculapius to industrial doctors in England today. He was Charles Turner Thackrah (1795-1833), a man who in his short life did a tremendous amount for the health of the working population. His interests lay chiefly in the textile industry. Let us therefore take a brief look at the economic and technical development of this industry.

As regards the structure of industry, a distinction is drawn between handicrafts, domestic industry, manufacturing industry, and, finally, the factory. The old system, in which production and capital were still separate, gave way to the manufactory, in which the owner of the capital and the works manager were one and the same person. In Protestant countries first (Holland, 1589), and later in others, these manufactories became associated with workhouses, in which people were trained by force to be useful members of human society. The transition to the factory, i.e. to a capitalist system of production, was accomplished in the manner already described and was due basically to the fact that the economy had been freed from monopolistic tendencies.

The production and printing of fabrics had already cccupied a dominant place in the earlier types of manufacture-also in Eastern Switzerland, for example-but the invention of the spinning frame by Arkwright in 1769 brought about a complete revolution in the English textile industry. The mechanical weaving loom, and later the Jacquard loom, as well as the new type of motive power, secured for the factories around Manchester and Leeds a dominant position in the world market. As a result of this development India, which had hitherto had no competitors in the production of fine fabrics, was thrown back to the agrarian stage of civilization.

It was during this second phase of the Industrial Revolution, marked by the invention of steamdriven, tremendously productive machines, that Thackrah grew up in Leeds. Trained in London under Astley Cooper among others, he became one of the founders of the Leeds medical school, and of a still unbroken tradition in industrial medicine. This latter statement holds good not only for England, but also for the world in general, because his ideas were taken up in various countries-first in the United States, then in France and Germany. His short life was brought to an early close by pulmonary tuberculosis. The valuable little book he wrote contains one particularly impressive chapter. The full title of the book, which was recently republished in a facsimile edition (1957), is:
"The Effects of Arts, Trades, and Professions and of Civic States and Habits of Living, on Health and Longevity; with Suggestions for the Removal of many of the Agents which produce Disease, and shorten the Duration of Life". The book contains only 238 pages in this reproduction of the second edition of 1832. The first, less complete edition had appeared in 1831 .

During the 15 years in which he worked in the poor districts of Leeds, Thackrah acquired a deep insight into the world of the worker. Not only the factory, trade, and profession, but also living habits such as the devastating abuse of alcohol and sexual excesses exerted a dominant influence on health and longevity. "Suggestions" for the prevention of occupational diseases run through Thackrah's rich account like a continuous thread.

Like Bernardino Ramazzini, the creator of occupational medicine in the 17th century (Ramazzini, 1739), Thrackrah also acquired early in life a wealth of practical wisdom, which, allied to a real sympathy for his fellow creatures, guided his pen as he wrote the various chapters of his book.

This is impressively revealed by Thackrah in his chapter (pp. 70-84) on the "Workers in Flax". Here he makes special reference to the horrors of child labour, just as Villermé was to do in France eight years later (1840). With the aid of 14 case histories he describes not only the important role played by irritation of the respiratory tract, but also the early damage to health suffered by these children. Worthy of note are the detailed proposals for preventing these diseases. One of the general conclusions of this chapter runs as follows (p. 119): "Dust is the great bane of manufacturers, and whether it be farina, animal or vegetable fibre, or evolved from minerals, stone, lime, coal or metal, it injures the respiratory organs, in proportion to the mechanical irritation it induces on the bronchial membrane."

This quotation reveals, with its oblique reference to pneumoconiosis-a disease which was just beginning to be studied at that time-the dawn of a new era in the study of occupational diseases. Hence, English doctors, who were soon to be joined by an enterprising band of Scottish physicians, were among the initiators of industrial medicine which has become such an important field of study today. The fact that healthy working conditions are the rule nowadays in factories and, to a large extent, in mines as well, is a tribute to the endeavours of that generation of doctors. Millions of our contemporaries owe them a permanent debt of gratitude.

In his poem "The Happy Ship of Zurich", the Alsatian Johann Fischart expresses a timeless truth in the following simple words: "For nothing is 
so difficult that it cannot be overcome by work". May this apt sentence also apply to the future labours of doctors of all nations, who are responsible for health!

The author wishes to thank Mr. Ian C. W. Bigland, Pharmaceutical Department, CIBA, Basle, for translating this paper into English.

\section{REFERENCES}

Buess, H. (1961). Die Erforschung der Berufskrankheiten bis zum Beginn des industriellen Zeitalters. Hdb. ges Arbeitsmed, Beginn des industriellen Zeitalters. Hdb. ges A

Hunter, D. (1957). The Diseases of Occupations, 2nd ed. English Universities Press, London.

Joël, K. (1929-1934). Wandlungen der Weltanschauung, Vol. II. Mohr, Tübingen.
Lesky, Erna (1956). Arbeitsmedizin im 18. Jahrhundert. Verlag des Notringes der wissenschaftlichen Verbande Oesterreichs, Vienna.

Meiklejohn, A. (1959). Brit. J. industr. Med., 16, 68.

Michel, E. (1953). Sozialgeschichte der industriellen Arbeitswelt, 3rd ed. Knecht, Frankfurt.

Percival, T. (1773). Essays Medical and Experimental, 2nd ed., Vol. 2. Johnson, London.

(1776). Philosophical, Medical, and Experimental Essays. Johnson, London.

Philosophical Transactions (1665). Vol. I. Royal Society.

Ramazzini B. (1739). Opetira omnia. Editio quarta Paul and Isaac Vaillant, London. (First edition appeared in 1700)

Rosen, G. (1943). The History of Miners' Diseases. Schuman's, New York. (1958). . The Life, Work and Times of Charles Turner Thackrah, surgeon and apothecary of Leeds (1795-1833), and The Effects of Arts, Trades and Professions, and of Civic States and Habits of Living, on Health and Longevity. facsimile of 2 nd ed. of Thackrah's book, 1832, ed. A. M. Meiklejohn, preceded by Meiklejohn's biography of Thackrah. Livingstone, Edinby Meiklejohn's biogra

Villermé, L. R. (1840). Tableau de l'état physique et moral des ouvriers, Vols. 1 and 2. Renouard, Paris. 